\title{
The specificity of work at the Emergency Medical Services and the psychological support of medical rescuers
}

\author{
Specyfika pracy w Państwowym Ratownictwie Medycznym a wsparcie psychologiczne \\ ratowników medycznych
}

\author{
Grzegorz Wójcik ${ }^{凶}$, Izabela Kaczmarek, Krzysztof Zdziarski, Konrad Jakubowski
}

Pomorski Uniwersytet Medyczny w Szczecinie, Zakład Interwencji Klinicznych i Medycyny Katastrof, ul. Chłapowskiego 11, 70-103 Szczecin

Pomeranian Medical University, Department of Clinical Interventions and Medicine Disasters

$\triangle$ grzegorz.wojcik@pum.edu.pl

\begin{abstract}
Introduction: Professional work is an extremely important aspect of the life of an adult. Probably we all want to be satisfied with this, and not just financially. It can be a source of positive experiences, but also a huge negative burden. It often generates and provides us with many adverse reactions, strains or stresses. The aim of the study was to determine the current status of psychological support to Medical Rescue Teams, and the opinions of medical rescuers on the need for psychological help in their work. Materials and methods: A questionnaire was addressed to medical rescuers across the country; 115 respondents participated in the study. It was conducted in April 2016. A statistical analysis of results was performed using the statistical package PQStat ver. 1.6. Analyses of dependences were carried out with $\chi^{2}$ tests. Significance was considered at $\mathrm{p}<0.05$, and highly significant was taken at $\mathrm{p}<0.01$.

Results: Almost $90 \%$ of respondents had never taken part in a psychological workshop. About $80 \%$ of medical rescuers had never participated in training courses on the techniques of relieving tension. In the workplaces of 98 (85.2\%) of the medical rescuers, there had never been any group meetings held in which
\end{abstract}

stress was relieved via conversation. Sometimes such meetings were held in the workplaces of $17(14.8 \%)$ of the medical rescuers. More than the half of respondents, 72 (62.6\%) people, believe that such meetings are definitely needed and could be effective. Conclusions: 1 . The current level of psychological support for Medical Rescue Teams is negligible. Only in a few workplaces it is offered to the medical rescuers. The majority of the study group were not provided access to a psychologist. 2. Medical rescuers believe that the profession requires working with a psychologist, and this cooperation should be ensured by the employer. 3. In $85.2 \%$ of cases there were no conversational meetings after difficult actions, with analysis and relieving of emotional tensions. If such meetings were held, almost $90 \%$ of respondents would participate. 4 . The current ways of reducing stress for medical rescuers are not always safe for their health and can lead to addictions. A possible cause is non-attendance by the majority in workshops on the techniques of relieving tension and psychological training.

Keywords: EMS; psychological support; working conditions; stress.

\begin{abstract}
ABSTRAKT
Wstęp: Praca zawodowa jest niezwykle ważnym aspektem w życiu dorosłego człowieka. Prawdopodobnie wszyscy dążą do tego, aby czerpać z niej satysfakcję, nie tylko finansową. Może być ona źródłem wrażeń pozy tywnych, ale i negatywnych - niejednokrotnie wywołuje wiele niepożądanych reakcji, obciążeń czy stresu.

Celem badania było określenie obecnej sytuacji związanej ze wsparciem psychologicznym w Zespołach Ratownictwa Medycznego oraz poznanie opinii ratowników medycznych na temat potrzeby pomocy psychologicznej w ich miejscach pracy. Materiały i metody: W badaniu, które zostało przeprowadzone w kwietniu 2016 r., wzięło udział 115 respondentów. Kwestionariusz ankiety skierowany był do ratowników medycznych z całego kraju. Analizy wyników przeprowadzono za pomocą pakietu statystycznego PQStat wersja 1.6. Analizy zależności przeprowadzono testem zależności $\chi^{2}$. Za istotne przyjęto prawdopodobieństwo testowe na poziomie $\mathrm{p}<0,05$, a za wysoce istotne przyjęto prawdopodobieństwo testowe na poziomie $\mathrm{p}<0,01$.
\end{abstract}

Wyniki: Niespełna 90\% respondentów nigdy nie brało udziału w warsztatach psychologicznych. Około 80\% ratowników medycznych nigdy nie uczestniczyło w szkoleniach z technik rozładowywania napięcia. W miejscach pracy $98(85,2 \%)$ ratowników medycznych nigdy nie odbywały się spotkania grupowe, podczas których stres byłby rozładowywany poprzez rozmowę. Czasami takie spotkania organizowane są w zakładach pracy u $17(14,8 \%)$ ratowników medycznych. Ponad połowa ankietowanych, $72(62,6 \%)$ osoby, uznaje takie spotkania za potrzebne i przypuszcza, że mogą być skuteczne.

Wnioski: 1. Obecnie możliwość wsparcia psychologicznego w Zespołach Ratownictwa Medycznego jest znikoma. Tylko w nielicznych zakładach pracy jest ona oferowana. W większości badanej grupie nie zapewnia się dostępu do psychologa. 2. Ratownicy medyczni uważają, że zawód ten wymaga współpracy z psychologiem, która powinna być zapewniona przez pracodawcę. 3 . W 85,2\% po trudnych akcjach nie odbywają się spotkania w celu rozmowy, analizy i wyładowania napięcia emocjonalnego. W przypadkach, w których takie spotkania byłyby organizowane, uczestnictwo w nich zdeklarowało 
prawie $90 \%$ badanych. 4 . Sposoby redukowania stresu przez ratowników nie zawsze są bezpieczne dla ich zdrowia i mogą prowadzić do uzależnień. Możliwą przyczyną jest nieuczestniczenie przez większość ratowników medycznych w warsztatach $\mathrm{z}$ technik rozładowywania napięcia oraz szkoleniach psychologicznych.

Słowa kluczowe: ratownictwo medyczne; wsparcie psychologiczne; warunki pracy; stres.

\section{INTRODUCTION}

On October 25, 2016, a tragic traffic accident happened in the vicinity of Zgorzelec (Poland) in which a car driver was killed on the spot, together with 3 juvenile children. After the rescue action, the officers of the Police and the Fire Department that were directly participating in the action were relieved of duty in order to have an appointment with a psychologist. The Emergency Medical Team, however, were called for another emergency - gastrointestinal bleeding.

Professional work is an extremely important aspect of the life of an adult. Probably we all want to be satisfied with it, and not just financially. It can be a source of positive experiences, and also a huge negative burden. It often generates and provides us with many adverse reactions, strains and stresses. Work contributes to our overall satisfaction and quality of life and determines the state of our health. According to the European Agency for Safety and Health, there are professional groups that are particularly vulnerable to stress, and in consequence negative aspects. These include e.g. health service and social assistance. This, in turn, is associated with psychosocial health problems [1]

In Poland, the profession of a medical rescuer should no longer be regarded as relatively young. Formally, it was created on the day the Law on Emergency Medical Services in Poland came into force in 2007, but people working in the ambulance service had already been performing similar work. Currently, while choosing to work as a medical rescuer, we also conform with the high demands imposed by this occupation and the psychological burden. The choice of study in no way verifies any personal predispositions, which in turn results in random people in the profession. Emergency medical services are not like the Police, Fire Brigade and Army, in which the mental aptitude of the candidates is examined during the selection stage. This work does require not only high mental toughness, but also great qualified psychological assistance, education in techniques of relieving stress, and support from colleagues. This element in Poland is very often unsung.

\section{HEALTH PROBLEMS IN THE WORK OF A MEDICAL RESCUER}

\section{Difficult situations, stress, and post-traumatic stress disorder (PTSD)}

The occupation of a medical rescuer is associated with many health burdens. In addition to the physical or shift work, medical rescuers are exposed daily to situations that can cause psychological discomfort. It happens that the balance in the system of co-operation created by a team of medical rescuers is compromised by the patients or the current situation. The imbalance is affected by many factors that we very often are not aware of. Starting with the simplest of factor of deprivation, when a given human need is not satisfied, e.g. hunger, sleep or safety, which is distracting for the person and stimulates negative emotions; and ending with the most dangerous, or a threatening situation, which may include: stinging with a needle, an attack by the patient or their family, contact with infectious diseases or just the fear of the occurrence of such situations. The situation of overburdening (being on duty more than $12 \mathrm{~h}$ ), results in fatigue of a medical rescuer, for whom it is often impossible to rest because of the number of interventions, as well as the adverse social conditions of the work. Apart from the hazards caused by the work, we need to mention others, e.g. any conflict with the administration or co-workers, and the situation of difficulties caused by defective equipment or lack of equipment, no skills and knowledge or the pressure of the environment [2]. The way in which the medical rescuer will respond to traumatic situations depends on his/her individual predispositions. However, even a person with high psychological resistance who is subjected to continuous emotional tensions, the dynamic of a rescue action, and the health and life hazards, may suffer an internal collapse of the regulatory system. The most effective method of defense against the occurrence of the adverse effects of trauma is to get a sufficiently high knowledge of both the field of emergency medicine and psychology [3]. Unfortunately, nothing is able to protect us completely from the trauma, especially when a medical rescuer is confronted with the elements causing stress. These include: a contact with death, a sense of helplessness, rapid consequences of events or deferred consequences. It is worth mentioning here the published work of Jeffrey Michell (a former fireman and the co-founder of the International Foundation ICICF, helping traumatized people) that includes a list of the most critical situations that may occur on duty:

1) death;

2) the suicide of a colleague;

3) a serious injury while being on duty;

4) an event like a disaster, an act of terrorism with many victims;

5) an event with a high degree of risk to the medical rescuers;

6) serious accidents concerning children;

7) events in which the victims are friends of the medical rescuers;

8) events surrounded by an intense media interest;

9) each event that is significant, shattering and causes suffering.

All of these factors can occur during the work of a medical rescuer.

According to The United Nations, stress is the "global epidemic of the twentieth century". Its levels are different and are 
determined by the methods of dealing with this phenomenon. There are so-called "universal stressors" which hit the security of the person, put them in the situation of very high requirements, exhausting all previous options for that person to meet them. They often attack suddenly, and reflect a trace in the psyche which, when combined with a similar stimulus of past events, may be reactivated [4]. In psychological terms, stress affects a loss of optimism, it causes a feeling of lack of sense of life in a person, lack of strength to meet daily requirements, lack of security and control of their own destiny. The power felt with the consequences of stress depends on the drama of the action, the duration of the event and the lag between the event and current situation, the type of experienced harm and possession or non-possession of the adequate support [2].

Acute stress (ASD) is a direct response to heavy events. It is manifested by psychological symptoms, i.e. irritability, anger, self-blame, blaming others, isolation, withdrawal, fear of the repetition of the disaster, feeling of stupor, numbness, feeling of being crushed, feeling of helplessness, mood swings, sadness, depression, grief, denial, impaired memory and attention, and physiological symptoms, i.e. loss of appetite, headache, diarrhea, stomach pain, nausea, hyperactivity, increased consumption of alcohol and drugs, nightmarish dreams, difficulty with sleeping, fatigue, decrease of energy [5].

Another consequence of difficult events can be post-traumatic stress disorder (PTSD), an anxiety disorder [6]. According to research on medical rescuers, those that are the most vulnerable to post-traumatic stress are in their middle age. Women have higher rates of PTSD than men, and are more prone to psychological symptoms such as depression or anxiety. A person who has experienced post-traumatic stress may have such overwhelming thoughts and feelings that they will consequently avoid situations reminding them of the trauma. Eventually, the person may avoid work, or the thoughts can affect the quality of the activities performed by a medical rescuer. In situations in which the medical rescuer finds in the victim any resemblance to himself or herself, a family member, a friend, or identifies the life situation of the victim with their own, or when independent reasons affect his or her inability to undertake a rescue operation, or such an action ends in a failure, there is an increased susceptibility to the negative effects of trauma, guilt, anger, decrease of self-esteem and self-confidence. Post-traumatic stress disorder symptoms can persist for up to 40 years, which should be treated as the whole professional life $[7,8]$.

The aim of the study was therefore to determine the current situation of psychological help for the Medical Rescue Teams in Poland and the opinions of medical rescuers on the need of psychological help in their work.

\section{MATERIALS AND METHODS}

A questionnaire was addressed to medical rescuers across the country; 115 respondents participated in the study. It was conducted in April 2016.
The analyzes of results were performed using the statistical package PQStat ver. 1.6. Analyzes of dependence were carried out with $\chi^{2}$ tests. Significance was considered at $p<0.05$, and highly significant was $\mathrm{p}<0.01$.

\section{RESULTS}

The test group comprised 67 (58.3\%) men and 48 (41.7\%) women. Most of the respondents were between 20-30 years ( $\mathrm{n}=88,76.5 \%$ ).

In the test group, 102 people ( $88.7 \%$ ) believed that working in medical teams requires cooperation with a psychologist to cope with the tension caused by the work. The opposite view was admitted by 13 medical rescuer (11.3\%).

Almost $90 \%$ of respondents had never taken part in psychological workshops. About $80 \%$ of medical rescuers had never participated in training courses in the techniques of relieving tension.

For 98 (85.2\%) medical rescuers, there had never been any workplace meetings held in which stress was relieved through conversation. Sometimes such workplace meetings were held for $17(14.8 \%)$ medical rescuers. More than half of the respondents, 72 (62.6\%) people, believed that such meetings are definitely needed and could be effective.

In the test group, 99 (86.1\%) medical rescuers believed that the workplace in which they worked should definitely provide access to a psychologist. None of the respondents chose the answer "definitely not". The opportunity to embrace the help of a psychologist was offered in the workplace of $25(21.7 \%)$ of respondents; 90 (78.3\%) medical rescuers did not have such an opportunity - Table 1.

The frequency of social meetings is significantly related to the gender $(\mathrm{p}<0.05)$. They are more common among women. The frequency of use of nicotine is highly significant in relation to education $(p<0.01)$. It is most common in the group with the lowest level of education. The frequency of indicating sport is related to education ( $\mathrm{p}<0.05)$, it is most common in the group with undergraduate education (Tab. 2 and 3 ).

\section{DISCUSSION}

The effectiveness of human work is not only due to abilities, competence and experience. An extremely important factor, often neglected, is the psychological aspect of work and individual skills to deal with it. A study conducted on athletes is worth mentioning here; it was stated that the physical results of the top athletes are very close to each other, and the biggest "deposits" of opportunities lie in the psychological aspect. Today, almost each sports team or top player has a psychologist or works with one. Regardless of the individual abilities of each employee, they should also be able to develop psychologically within the training and professional work.

To make an employee effective, they should be provided with good working conditions, take care of their health and 
TABLE 1. The distribution of answers about ways to relieve stress induced in work - depending on gender and education

\begin{tabular}{|c|c|c|c|c|c|c|c|c|c|c|c|}
\hline \multirow{2}{*}{\multicolumn{2}{|c|}{ Answers }} & \multicolumn{2}{|c|}{ Woman } & \multicolumn{2}{|c|}{ Man } & \multicolumn{2}{|c|}{ College } & \multicolumn{2}{|c|}{ Undergraduate } & \multicolumn{2}{|c|}{ Graduate \& doctorate } \\
\hline & & $\mathrm{n}$ & $\%$ & $\mathrm{n}$ & $\%$ & $\mathrm{n}$ & $\%$ & $\mathbf{n}$ & $\%$ & $\mathbf{n}$ & $\%$ \\
\hline \multicolumn{2}{|l|}{ Alcohol } & 10 & 21 & 15 & 22 & 5 & 14 & 12 & 22 & 8 & 32 \\
\hline \multicolumn{2}{|l|}{ Nicotine } & 12 & 25 & 23 & 34 & 20 & 56 & 12 & 22 & 3 & 12 \\
\hline \multicolumn{2}{|l|}{ Intoxicants } & 3 & 6 & 6 & 9 & 1 & 3 & 6 & 11 & 2 & 8 \\
\hline \multicolumn{2}{|l|}{ Sport } & 21 & 44 & 36 & 54 & 11 & 31 & 33 & 61 & 13 & 52 \\
\hline \multicolumn{2}{|l|}{ Music } & 26 & 54 & 38 & 57 & 16 & 44 & 35 & 65 & 13 & 52 \\
\hline \multicolumn{2}{|c|}{ Meetings with friends } & 33 & 69 & 33 & 49 & 15 & 42 & 34 & 63 & 17 & 68 \\
\hline \multirow{3}{*}{ Alcohol } & $x^{2}$ & \multicolumn{4}{|c|}{0.04} & \multicolumn{6}{|c|}{2.86} \\
\hline & df & \multicolumn{4}{|c|}{1} & \multicolumn{6}{|c|}{2} \\
\hline & $p$ & \multicolumn{4}{|c|}{0.8420} & \multicolumn{6}{|c|}{0.2395} \\
\hline \multirow{3}{*}{ Nicotine } & $x^{2}$ & \multicolumn{4}{|c|}{1.15} & \multicolumn{6}{|c|}{16.46} \\
\hline & $\mathrm{df}$ & \multicolumn{4}{|c|}{1} & \multicolumn{6}{|c|}{2} \\
\hline & $p$ & \multicolumn{4}{|c|}{0.2837} & \multicolumn{6}{|c|}{0.0003} \\
\hline \multirow{3}{*}{ Intoxicants } & $x^{2}$ & & & & & & & & & & \\
\hline & df & & & & & & & & & & \\
\hline & $p$ & & & & & & & & & & \\
\hline & $x^{2}$ & & & & & & & & & & \\
\hline Casual sex & $\mathrm{df}$ & & & & & & & & & & \\
\hline & $p$ & & & & & & & & & & \\
\hline Sport & $\mathrm{df}$ & & & & & & & & & & \\
\hline & $p$ & & & & & & & & & & \\
\hline & $x^{2}$ & & & & & & & & & & \\
\hline Music & $\mathrm{df}$ & & & & & & & & & & \\
\hline & $\mathrm{p}$ & & & & & & & & & & \\
\hline & $x^{2}$ & & & & & & & & & & \\
\hline $\begin{array}{l}\text { Meetings } \\
\text { with friends }\end{array}$ & $\mathrm{df}$ & & & & & & & & & & \\
\hline & $p$ & & & & & & & & & & \\
\hline
\end{tabular}

TABLE 2. The distribution of answers about stressful situations at work

\begin{tabular}{lcc}
\multicolumn{1}{c}{ Answer } & $\mathbf{n}$ & $\%$ \\
\hline Contact with death & 35 & 30.7 \\
\hline Dealing with children & 42 & 36.8 \\
\hline Accidents & 41 & 36.0 \\
\hline Dealing with elderly people & 3 & 2.6 \\
\hline Informing about patient's death & 40 & 35.1 \\
\hline Faulty equipment & 50 & 43.9 \\
\hline Contact with administration/supervisor & 42 & 36.8 \\
\hline Too many hours at work & 25 & 21.9 \\
\hline Too many duties & 34 & 29.8 \\
\hline Other & 10 & 8.8 \\
\hline
\end{tabular}

physical condition, and psychosocial status. Having the right procedures to make the provision of security of occupational health and safety is an insufficient element of the efficient functioning of workers and the efficient work system that brings certain perks. In particular, when the work is based on contact with people. When it comes to the medical rescuers and work with the patients, their family and the medical staff, it is important to maintain the intact mental balance of the rescuer. Unfortunately, it is not easy to remain neutral to a tragedy, illness or death. Despite the fact that such incidents are usually short-lived, the emotions that remain after them may have long-term consequences. To return to proper mental health, adequate knowledge is needed concerning the skills of struggling with symptoms resulting from traumatic events and stress, and the ability to recognize early signs of e.g. PTSD. However, knowledge may not be enough. Therefore, 
TABLE 3. The distribution of answers to the question "Do you think that meetings with a psychologist are necessary and effective?" - depending on gender and education

\begin{tabular}{|c|c|c|c|c|c|c|c|c|c|c|}
\hline \multirow[t]{2}{*}{ Anwers } & \multicolumn{2}{|c|}{ Woman } & \multicolumn{2}{|c|}{ Man } & \multicolumn{2}{|c|}{ College } & \multicolumn{2}{|c|}{ Undergraduate } & \multicolumn{2}{|c|}{$\begin{array}{c}\text { Graduate \& } \\
\text { doctorate }\end{array}$} \\
\hline & n & $\%$ & $\mathrm{n}$ & $\%$ & n & $\%$ & n & $\%$ & n & $\%$ \\
\hline Definitely yes & 31 & 65 & 41 & 61 & 22 & 61 & 31 & 57 & 19 & 76 \\
\hline Definitely no & 1 & 2 & 3 & 4 & 1 & 3 & 1 & 2 & 2 & 8 \\
\hline Neutral but I would not participate if I was invited & 2 & 4 & 6 & 9 & 3 & 8 & 5 & 9 & 0 & 0 \\
\hline Neutral but I would participate if I was invited & 14 & 29 & 17 & 25 & 10 & 28 & 17 & 31 & 4 & 16 \\
\hline$x^{2}$ & \multicolumn{4}{|c|}{1.58} & \multicolumn{6}{|c|}{6.67} \\
\hline df & \multicolumn{4}{|c|}{3} & \multicolumn{6}{|c|}{6} \\
\hline $\mathrm{p}$ & \multicolumn{4}{|c|}{0.6632} & \multicolumn{6}{|c|}{0.3520} \\
\hline
\end{tabular}

it should be necessary to provide the medical rescuers with access to a psychologist who would be able to respond au courant and, properly help to counter common problems. Such psychological support and appropriate knowledge of the medical rescuers should have regard to the welfare of the general staff and the organization in which they work.

It is extremely important that when analyzing an event in which we have taken part, to focus not only on the formal aspects such as rescue procedures during and after the action, but also on organizing therapeutic meetings - debriefing for all involved in the incident [9]. Such a need is confirmed in test results in which the vast majority (62.6\%) of respondents believe that meetings are necessary and effective. Almost 90\% of the medical rescuers would participate in such meetings, which only emphasizes the importance of the situation, that is the need for meetings. These results also demonstrate the high awareness of the medical rescuers in this field. It is worth noting that such meetings do not take place in the workplaces of $85.2 \%$ of respondents. In the other case $(14.8 \%)$, such meetings are held occasionally. These results conclude that this topic in most cases is avoided by employers and society, and the rescuers themselves are increasingly aware of the seriousness of the situation [9].

The occupation of the medical rescuer, according to the employees, should be based on cooperation with a psychologist, which is confirmed by the result of $88.7 \%$. However, such help is usually organized independently, because $78.3 \%$ of the respondents do not have such a possibility in their workplace. Among medical rescuers $86.1 \%$ are in favor of stating that the employer should provide them with a psychologist. It is noteworthy that every fifth respondent has a feeling that such assistance is very needed (17.6\%), and over half of the sample group state that they would gladly benefit from such assistance $(66.7 \%)$. At the same time, at the time of testing, every tenth (7.1\%) respondent had used the help of a psychologist. Importantly, assistance was associated with problems resulting from the occupation.

In analyzing the results of the research, unfortunately, the dramaturgy of this professional group should be noted. At present, medical rescuers are people with higher education, having more and more knowledge in this area. Therefore, individual feelings of employees and lack of intervention in the workplace are frightening, which undoubtedly may reflect on the effectiveness of the work.

\section{CONCLUSIONS}

1. The current situation of psychological help in the Medical Rescue Teams is negligible. Only in very few workplaces it is offered for the medical rescuers. The majority of the study group are not provided with access to a psychologist.

2. Medical rescuers believe that the profession requires working with a psychologist, and this cooperation should be ensured by the employer.

3. In $85.2 \%$ of cases there are no conversational meetings after difficult actions, with analysis and relieving emotional tension. When such meetings would be held, almost $90 \%$ of respondents would participate.

4. The ways of reducing stress by medical rescuers are not always safe for their health and can lead to addiction. A possible cause is the non-participation by the majority in the workshops of the techniques of relieving tension and psychological training.

\section{REFERENCES}

1. Hetherington A. Wsparcie psychologiczne w służbach ratowniczych. Gdańsk: Gdańskie Wydawnictwo Psychologiczne; 2004.

2. Kołodziej B. Potrzeba wsparcia psychologicznego ratowników medycznych w kontekście wsparcia psychologicznego funkcjonariuszy policji i straży pożarnej. J Ecol Health 2011;15(1):35-8.

3. Ozer EJ, Best SR, Lipsey TL, Weiss DS. Predictors of posttraumatic stress disorder and symptoms in adults: a meta-analysis. Psychol Bull 2003;129(1):52-73.

4. Schnurr PP, Green BL. Understanding relationships among trauma, posttraumatic stress disorder, and health outcomes. Adv Mind Body Med 2004;20(1):18-29.

5. Dąbkowska M. Rozpoznawanie zespołu stresu pourazowego. Neuropsychiatr Neuropsychol 2008;3(2):80-4.

6. Gulcz M, Polak M. Zastosowanie terapii poznawczo-behawioralnej w leczeniu wybranych zaburzeń lękowych: zespół lęku napadowego i PTSD. Nowiny Psychologiczne 2002;2:29-49.

7. Koniarek J, Dudek B. Zespół zaburzeń po stresie urazowym a stosunek do pracy strażaków. Med Pr 2001;52(3):177-83.

8. Papiernik B, Holajn P, Żak-Jasińska K, Basiński A. Zespół stresu pourazowego w pracy zawodowej ratowników medycznych. Anest Ratow 2012;6:339-42.

9. Magyar J, Theophilos T. Review article: Debriefing critical incidents in the emergency department. Emerg Med Australas 2010;22(6):499-506. 